ropy` u yevropejs 'ky`j soyuz: istory`chni peredumovy`, etapy`, rezul`taty`], URL: https:// scijournals.pnu.edu.ua/index.php/politics/article/view/4043/4639 (in Ukrainian).

16. Fara, D. M. (2004). A country looking for its way [Strana, y`shhushhaya svoj put . Sovremennaya Evropa], 2, p. 57-68 (in Russian).

17. Lozhechkin, V. S. Stages of European integration of the Republic of Poland (19892004) [Etapy` yevropejs 'koyi integraciyi Respubliky` Pol’shha (1989-2004 rr.)], Nauka. Religiya. Suspil stvo, 2, p. 49-53 (in Ukrainian).

18. Sin ova, L. M. (2017). Problems of legislative provision of social benefits in the conditions of Ukraine's European integration [Problemy`zakonodavchogo zabezpechennya social `ny`x dopomog v umovax yevrointegraciyi Ukrayiny`], Social ’ne pravo, 2. p. 113-120 (in Ukrainian).

19. Xalecz'ka, L. P. (1999). France's position on the problem of enlargement of the European Union to the East [Pozy`ciya Franciyi z problemy` rozshy`rennya Yevropejs 'kogo Soyuzu na Sxid], Visny `k Ky yivs ’kogo universy `tetu imeni Tarasa Shevchenka, 42, p. 64-68 (in Ukrainian).

20. Karpchuk, N. P. (2017). Polish public diplomacy as a factor of European integration [Publichna dy`plomatiya Pol`shhi yak chy`nny`k Yevropejs `koyi integraciyi], Mizhnarodni vidnosy 'ny' seriya «Polity 'chni nauky`», 15, p. 96-107. (in Ukrainian).

Матеріал надійшов до редакиії 07.01.2021 p.

УДК 351.862.4(477:470)

Natalia Nikolaienko,

Doctor of Political Sciences, Full Professor,

National University of Shipbuilding named after Admiral Makarov,

ORCID ID 0000-0002-2558-4749

nikvlad96@ukr.net

DOI 10.29038/2524-2679-2021-01-273-283

\title{
RUSSIAN AGGRESSION AS A CHALLENGE IN THE SPHERE OF UKRAINE'S NATIONAL SECURITY
}

It's stated that the annexation of Crimea and Russian-Ukrainian hybrid war in Eastern Ukraine is a threat and a challenge not only to Ukraine's national security, its sovereignty but also to the contemporary world order. Ukrainian political system has not yet formed an appropriate and effective means and mechanisms to counter Russian hybrid expansion. The author underscore that it is impossible to ensure national security of Ukraine today, using only traditional approaches combined to improve the state security functions or satisfy some narrow interests. This approach is ineffectual and also stimulates overspending

(C) Nikolaienko N., 2021 
of public resources and leads to duplication of the central authorities' functions, and sometimes even starts threat to the state's national interests. Russian aggression is the result of ineffectual government policies, rising corruption, and lack of sufficient resources to ensure living standards of the population. It is proved that for Russia the war with Ukraine is a perfect way to overcome the dysfunctional private system, as cheap media and small losses not only ensured survival but also laid the possibility of prolonged exposure to other geopolitical players, and development trends in the geopolitical environment.

Key words: challenges, aggression, national security, hybrid warfare, security area, political system, elite, corruption, society, authorities.

\section{INTRODUCTION}

The Russian aggression, which began in February 2014, revealed the devaluation of the national security structures of the Ukrainian state and confirms the challenge to its statehood. In this regard, the question of the need to analyze national security in the Russian-Ukrainian hybrid war is raised.

Nowadays the most topical problem for Ukraine is Russia's aggression aimed at destabilizing the internal situation within the state, loss of public legitimacy by the state leadership and chaotic political processes.

Today, the world can observe one of the longest and bloodiest hybrid wars in human history. This war was called the Russian-Ukrainian hybrid war. The fighting has been taking place on the territory of the Ukrainian state for the seventh year in a row, and none of the leading experts on this issue is able to make an accurate predictions about its further duration. There is no doubt that this is a hybrid aggression. This confirms the scale of hostilities in the east of the Ukrainian state with the involvement of mercenaries and military personnel from the neighboring country or open intervention in the Autonomous Republic of Crimea with the subsequent annexation of the peninsula. Also, the confirmation of the hybrid war is the deployment of an information attack by the aggressor states with the use of certain destructive political and social technologies.

The annexation by the Russian Federation of the Ukrainian territory the Autonomous Republic of Crimea and Sevastopol, parts of the Donetsk and Lugansk regions, and building such quasi-states as «Donetsk People's Republic» and «Lugansk People's Republic» prove that studying of the principles and mechanisms of Russian invasion requires a comprehensive research in an ongoing hybrid war.

According to the author, it is appropriate to use the definition «RussianUkrainian warfare» when analyzing Russia's aggression against Ukraine. 
The problem of Russia and Ukraine's conflict, Russia's aggression is relevant and debatable, and it continues to draw attention of both foreign and domestic scientists, analysts who are not indifferent to the problem of Russia's undeclared war against Ukraine.

Theoretical Basis of the Study. A considerable number of foreign (F. Hoffman, J. Mattis, B. Renz, H. Smith) and domestic scientists (O. Levchenko, Ye. Mahda, V. Gorbulin, G. Pocheptsov) have devoted their researches to studying of hybrid warfare phenomenon.

The Purpose of the Article. The aim of the study is to identify the main challenges to the Ukrainian security space in the context of the RussianUkrainian hybrid war and to identify the main mechanisms for ensuring the national security of Ukraine.

Research Methodology. In the study research methods were used such as comparison, classification, theoretical modeling, elucidation of causal relationships, systematization, abstraction and specification, analysis of documentation and results of researchers on the problem of the study.

Russia's aggressive policy has illustrated itself in the military, political, economic, social, and humanitarian and information dimensions. In his paper Ye. Mahda states that hybrid war, in its wide meaning, is a set of preprepared and implemented military, diplomatic, economic and informational actions aimed at achieving strategic goals. Hybrid warfare components are the fallowing: universal and non-standard threats, terrorism, subversive actions when using the latest or non-template technologies to resist the enemy's advantage in military potential [3].

V. Horbulin was one of the first domestic researchers to point out the concept of «hybrid warfare» in Russia's actions against Ukraine. This kind of war is unique from a structural and functional point of view as it is «hybrid» in form and «asymmetric» in content. The most explicit nature of the new war was first demonstrated by Russia's annexation of the Autonomous Republic of Crimea in the spring of 2014, and further support for its actions by local radical elements and the full-scale invasion of the Russian units into the eastern regions of Ukraine. Although each specific element of this «hybrid warfare» is not new and has been used in almost all wars of the past, the coherence and interrelation of all the elements, the dynamism and flexibility of their implementation, and the increasing value of the information factor are unique [1].

The current Russian-Ukrainian warfare has been called a hybrid, because the confrontation with Russia's aggression and influence in various spheres is taking place not only on the front lines, but throughout the territory of 
Ukraine. We can identify such elements of a hybrid warfare as propaganda, which is based on outright lie, manipulation and substitution of concepts, denial of war and the Russian Federation's participation in this war; imputation Ukraine in its own crimes, distortion of facts in Ukrainian history; trade and economic pressure and energy blockade; terror and intimidation of Ukrainian citizens; cyberattacks and attempts to destabilize critical infrastructure. One can agree that several measures have been taken in Ukraine to counteract Russian propaganda aggression. Ukrainian government banned access to some Russian social networks, and strengthened cyber security (with international help). However, the Russian Federation maintains carrying out special information operations throughout Ukraine, using a variety of channels, including illicit media resources and social networks, undermining the country's reform processes [5].

\section{RESULTS OF THE RESEARCH}

Today's events in the East and the annexation of Crimea are the results of inefficient state policy, growing corruption, and the lack of sufficient financial resources to activate economic processes. A large territory, industrial districts and complexes were left to the mercy of local elites of eastern Ukraine. The only thing the local government cared about was a subvention from the state. This made it possible to parasitize at the level of the national economy, blackmailing the central government with actions of disobedience.

After the analysis of the Russian hybrid aggression (since 2014 until today), the authors conclude that it is hybrid in its character and mixed in the actions, technics and methods, changing role of the civilians, local public movements and political organizations and their transformation into active participants in forced confrontation.

However, an important aspect of the Russian-Ukrainian hybrid warfare is the use of the Russian Federation not only the military strategy of dismantling the Ukrainian statehood but also destroying its political institutions. It therefore threatens Ukraine's national security, causes the alliance with the enemy both individuals and organizations and structures. It also means that Russia actively made inroads into the Ukrainian authorities and vigorously pursued its recruitment policy in military and security forces.

As Hungarian researcher András Rácz points out that the use of the terms by NATO has been a breakthrough in the discourse of hybrid warfare and hybrid threats. Since July 1, 2014, Alliance representatives have publicly and openly indicated that an alternative of warfare has become «hybrid war» 
(Hybrid war, 2014). Soon, this term was picked up by the world's leading media, and at the NATO Summit in Wales in September 2014, they proposed it to consider as hybrid «a broad range of highly integrated open and hidden military, paramilitary and civilian means» [9].

Russian aggression against Ukraine is based on two types of influence: internal and external. Thus, trying to put an appropriate pressure on Ukraine, Russia has created a political enclave of influential Ukrainian politicians, Ukrainian media, and public and cultural figures who supported its actions. Here is a statement on this topic made by British military analyst R. Thornton: «The Russian information product is designed to influence the mind. However, those affected should be properly trained. Moscow is in favor, since the new independent states that were part of the Soviet Union have many ethnic Russians, and Russian-speaking citizens. These Russian minorities in such countries as Ukraine, the Baltic States, Moldova and Georgia are the key objectives of the present Moscow information warfare campaign» [7].

Russian aggression as a challenge to the Ukrainian security space can be considered as a result of the transformation of the political system and development the Russian Federation, the main characteristics of which are the fallowing: ongoing links between business and state structures, the lack of a competitive environment, the formation of a resource allocation system according to the degree of loyalty.

For the Russian Federation, war with Ukraine is an ideal way of overcoming the dysfunctionality of its system. The point is that relatively cheap means and small losses ensure survival and also provide opportunities for permanent influence on other geopolitical players as well as on shaping trends in the geopolitical environment.

But at the same time, it should be noted that the development of the Ukrainian state, its economic, political and cultural potential had an unreliable basis. The corrupt structure of the economy and politics has also led to Russian aggression. If detailed, it is the corruption factors that can explain the lost opportunities for reform and European integration in the first stages of independence; the crisis of Maidan 2004 and pro-Russian lobby's rise to power; the failure of key reforms after the Dignity Revolution and a significant decline in citizens' standard of living.

Ukraine inherited from the Soviet Union an enormous part of the powerful industry, which became the economic foundation of the country in the process of its development. An instrument of Russian aggression was to gain control of all important objects of the Ukrainian industry. The use of political and social technologies of a destructive nature undoubtedly accompa- 
nied this process. The Russian, Ukrainian and European oligarchies played an active role in this issue. They accomplished the tasks with no or very little effort thanks to certain liaisons and influence on the Ukrainian power structure. The expansion and intensification of the impact of corruption in Ukraine has turned into a major mechanism in the invader hybrid war.

Of particular note is the fact that the use of energy potential as an «energy» weapon was announced in 2003 in the Energy Strategy of the Russian Federation until 2020. The document declared that Russia's powerful fuel and energy complex «is the basis of economic development, a tool of internal and foreign policies». And it was not just a declaration of intent, but a proper instrument of influence that Russia has repeatedly used to its advantage (including weakening by all means the energy infrastructure of potential adversaries) [7].

During the period of 1995-2004 a significant redistribution of influence among representatives of the Russian financial groups began in Ukraine. The objects of oil refining, chemical, machine-building, metallurgical spheres began to be actively bought up by Russian companies during that period. To take one example, a controlling stakes of the Mykolayiv Alumina and Lysychansk Refinery plants were bought and transited to the Siberian Aluminum Group and Alfa Group Consortium linked to Mikhail Friedman and Oleh Derypaska, who were among the most influential oligarchs in Russia. Subsequently, Oil Company Alfa-Group - Alfa-Nafta became the leader of the Ukrainian market for crude oil and oil products and provided influence and control over several regional oil supply companies.

It should be also noted that processes of oligarchization in the Ukrainian economy and Russia's control over the important objects of the Ukrainian state were accompanied by negative tendencies for ordinary Ukrainians, such as rising prices, unstable situation in the foreign exchange market, increasing utility tariffs. Nowadays lots of people are covered by apathy because of prolonged systemic crisis in which society has been placed, low living standards, uncertainty about the future. People lose faith that they can affect the state of affairs. Pro-government parties that try to keep their ratings at all costs, and as a result refuse to make any real transformations, take these factors into account.

During 2010-2013, there was a significant destabilization of state and security institutions. It was at this time that the undermining, demoralizing, and decline of the state authorities and power structures of Ukraine were actively taking place thru infiltration of agents disseminating Russian influence. They were also involved in making key decisions beneficial to the Russian Federation. As an example, almost all the leaders of the Ukrainian 
security forces during V. Yanukovych's presidency were agents of the Kremlin: D. Solomatin, Defense Minister (a citizen of the Russian Federation until 2005), O. Yakymenko, a chief of the Ukrainian Security Service (a citizen of the Russian Federation until 1998), V. Zakharchenko, a head of the Department of the Interior (moved to Russia after the Revolution of Dignity) (Levchenko, 2017). This situation led to the fact that the Ukrainian security forces were unable to respond in time to Russia's aggression in Crimea due to the betrayal and mass cross-overs to the side of the enemy made by the police and security officers of the Autonomous Republic of Crimea, in particular the betrayal of the appointed commander of the Ukrainian Navy Admiral D. Berezovsky and numerous demoralized and exposed to Kremlin propaganda officers and sailors [7].

Ukraine has not yet provided a reliable and competitive information alternative for the Russian-speaking population and those using the Russiancontrolled media. The professional skills of most Ukrainian officials and heads of regional administrations over the past five years also raise doubts among most experts and analysts.

Faced with growing hybrid threats to Ukraine, it is dangerous for the Ukrainian politicians and the society to underestimate the loss of psychological and cultural stability and integrity of the Ukrainian political nation. In our subjective opinion, the year 2019 has showed the poor quality of democracy and the strengthening of anti-liberal tendencies, the lack of effective communication of politicians with the society. This process has deepened distrust to the major state institutions and political forces.

Thus, Russia's aggression has exposed such problems in the Ukrainian security area as:

1. The main challenges to the Ukrainian security space have not been clearly identified for all the years of Ukraine's independence.

2 . The reluctance by present public authorities to analyze the security space and to identify threats in time, and a significant impact on leadership by other states, led to wrong management decisions on national security.

3 . The inability of political institutions to respond effectively to the challenges of the times.

4. Internal political instability and the political elites' inability to plan and implement a coherent country development strategy.

5. High level of political corruption, incompetence of the authorities and merging of business and power. For the sake of some preference the political elites are showing a strong willingness to make concessions to outside players damaging the national interests. 
6. The reduction in military forces during 2010-2013 led to catastrophic consequences. At the beginning of the Russia's aggression in March 2014, the total number of Ukrainian soldiers, ready for immediate fighting, did not exceed several thousand.

7. Difficult economic situation and economic disruption in the 1990s led to a consistent deterioration of the economic condition for most of the Ukrainians, energy dependence on Russia, stagnation of the internal exploitation of mineral resources. An oligarchic model of the economy created the conditions for the slowdown in economic growth and production processes.

8. The balance of development and innovation in the humanities and education has been disrupted, the proposed reforms have worsened the state of education and science, and the expert environment, based on grant programs, in most cases has served oligarchic groups.

\section{CONCLUSIONS AND PROSPECTS FOR FURTHER RESEARCH}

Of course, hybrid conflicts are not a completely new kind of confrontation between states. Elements of such wars were repeatedly used in the framework of the usual «big» and «small» wars. Itself through the duration of the legislative regulation of the introduction of special wines on the international level, the need for the establishment of hybrid methods in order to keep them out of the way. But over the past few decades, such methods have become detached from the elements of conventional wars and have become independent modernized wars of our time. The basis is no longer the military potential of the state, but the information potential in which the enemy competes for the beliefs and views of both the individual and the population as a whole in order to further capture the territory of another country or its «voluntary» accession to its territory.

Russia's aggression against Ukraine has started a new era in shaping the country's national security when the state institutions and civil society merge and develop a further strategy to protect Ukrainian security space, because in either case, there is a risk of collapse in Ukraine's political system or even the state breakup. The proclaimed reforms have no intrinsic motivation and are carried out under external pressure in anticipation of cash tranches. Business environment officials do not expect reforms to improve the investment climate. On the contrary, there is a control of the business, and increasing corruption rates. The priority areas of economic reform should be: anti-corruption policy, protection of creditors' rights, transparency of court decisions and improvement of the executive system, protection of property 
rights, detinization of the economy, improvement of the infrastructure. Today the state does not show its intention to ensure equality in the conditions of life for different social strata of the society. Benefits, promised to medium and small businesses, remain a dead letter, and big business stays in the shadows working under «individual schemes2.

Therefore, in the authors' opinion, besides winning the Russian-Ukrainian war, convincing steps should be taken in the following directions:

- reformatting the judicial system and the Constitutional Court, in particular, by defining the mechanism of the election of judges;

- building democratic party system, making it impossible for the oligarchic groups to influence it;

- carrying out systemic reforms in the economic sphere and administrative-territorial structure, employment creation, stimulation the development of small and medium business;

- real counteraction to corruption challenges;

- sound information and humanitarian policy aimed, first, at intellectual capacity-building of the Ukrainian state.

Today, the hybrid war between Ukraine and Russia is escalating, which means that Russia is using combined forms of hybrid war, including destructive political and social technologies, preparing for military aggression and manipulating the consciousness of the population in the occupied territories.

\section{СПИСОК ВИКОРИСТАНИХ ДЖЕРЕЛ}

1. Горбулін, В. П. (2015). Геополітичний реванш: від ідеї до стратегії. URL: https:// dt.ua/internal/gibridna-viyna-yak-klyuchoviy-instrument-rosiyskoyi-geostrategiyi-revanshu-_.html

2. Левченко, О.В.(2017). Еволюція гібридної війни Російської Федерації проти України, Наука і оборона, № 2, с. 11-16.

3. Магда, Є. (2014). Гібридна війна: сутність та структура феномену. Міжннародні відносини. Серія: Політичні науки. URL: http://journals.iir.kiev.ua/index.php/pol_n/article/viewFile/2489/222

4. Енергетична стратегія України на період до 2035 р. (проект). URL: http://mpe. kmu.gov.ua/minugol/control/uk/doccatalog/list?currDir=50358

5. Світова гібридна війна: український фронт (2017): монографія, за заг. ред. В. П. Горбуліна, Київ, НІСД, 496 c. URL: https://shron1.chtyvo.org.ua/Horbulin_Volodymyr/Svitova_hibrydna_viina_ukrainskyi_front.pdf?

6. Ніколаєнко, Н. О., Василевич, Ю. В. (2019). Сучасні суспільно-політичні тенденції розвитку України в контексті російсько-української гібридної війни, Гілея (науковий вісник), вип. 14, Київ, ВІР УАН, с. 82-85.

7. Почепцов, Г. Г. (2015). Гібридна війна: інформащійна складова. URL: http:// www.jimagazine.lviv.ua/2015/Pochepcov_Ros_konteksty_hibridnoj_vijny.html 
8. Hybrid war - hybrid response? NATO Review (2014). URL: https://www.nato.int/ docu/review/2014/Russia-Ukraine-Nato-crisis/Russia-Ukraine-crisis-war/EN/index.html

9. Wales Summit Declaration. NATO Official website (2014). URL: https://www.nato. int/cps/en/natohq/official_texts_112964.html

\section{АГРЕСІЯ РОСІЇ ЯК ВИКЛИК У СФЕРІ НАЦІОНАЛЬНОЇ БЕЗПЕКИ УКРАЇНИ}

У статті досліджено основні виклики українському простору безпеки в контексті російсько-української гібридної війни та визначено основні механізми забезпечення національної безпеки України. Російська агресія, яка розпочалася в лютому 2014 р., виявила девальвацію структур національної безпеки Української держави та свідчить про виклик для і1ї державності. У зв’язку з цим актуалізуються питання про необхідність аналізу національної безпеки в умовах російсько-української гібридної війни.

Зазначено, що анексія Криму та російсько-українська гібридна війна на Сході України є загрозою й викликом не лише політичній безпеці України, іiї суверенітету, а й сучасному світовому порядку. Українська політична система за роки агресії РФ ще не сформувала результативних засобів і механізмів протидії гібридній експансії.

Підкреслено, що сьогодні неможливо забезпечити національну безпеку України, використовуючи лише традиційні підходи, потрібно реформувати весь державний апарат, його функціональні обов'язки, також гуманітарну та освітянську сферу. Російська агресія є результатом неефективної державної політики, зростання корупції й відсутності достатніх ресурсів для забезпечення життєвого рівня населення. Доведено, що для Росії війна з Україною $\epsilon$ прекрасним способом подолання дисфункціональної системи, оскільки дешеві засоби масової інформації та невеликі втрати забезпечували виживання російській державній системі.

Ключові слова: виклики, агресія, національна безпека, гібридна війна, зона безпеки, політична система, еліта, корупція, суспільство, влада.

\section{REFERENCES}

1. Gorbulin, V. P. (2015). Geopolitichnij revansh: vid ideï do strategiï. URL: https:// dt.ua/internal/gibridna-viyna-yak-klyuchoviy-instrument-rosiyskoyi-geostrategiyi-revanshu-_html 
2. Levchenko, O. V. (2017). Evolyuciya gibridnoï vijni Rosijs'koï Federaciï proti Ukraïni, Nauka i oborona, 2. 11-16.

3. Magda, E. (2014). Gibridna vijna: sutnist' ta struktura fenomenu. Mizhnarodni vidnosini. Seriya: Politichni nauki. URL: http://journals.iir.kiev.ua/index.php/pol_n/article/ viewFile/2489/222

4. Energetichna strategiya Ukraïni na period do 2035 r. (proekt). URL: http://mpe.kmu. gov.ua/minugol/control/uk/doccatalog/list?currDir=50358

5. Svitova gibridna vijna: ukraïns'kij front (2017): monografiya, za zag. red. V. P. Gorbulina, Kyiv, NISD, 2017, 496 p. URL: https://shron1.chtyvo.org.ua/Horbulin_ Volodymyr/Svitova_hibrydna_viina_ukrainskyi_front.pdf

6. Nikolaєnko, N. O., Vasilevich, YU. V. (2019). Suchasni suspil'no-politichni tendenciï rozvitku Ukraïni v konteksti rosijs'ko-ukraïns'koï gibridnoï vijni, Gileya (naukovij visnik), 14, Kyiv, VIR UAN., p. 82-85.

7. Pochepcov, G. G. (2015). Gibridna vijna: informacijna skladova. URL: http://www. jimagazine.lviv.ua/2015/Pochepcov_Ros_konteksty_hibridnoj_vijny.html

8. Hybrid war - hybrid response? NATO Review (2014). URL: https://www.nato.int/ docu/review/2014/Russia-Ukraine-Nato-crisis/Russia-Ukraine-crisis-war/EN/index.html

9. Wales Summit Declaration. NATO Official website. (2014).

Матеріал надійщов до редакиії 17.01.2021 p.

УДК 327.8

\section{Олександр Соколовський,}

аспірант кафедри політології та міжнародних відносин,

Національний університет «Львівська політехніка»,

ORCID ID 0000-0002-0515-2367

oleksandr.b.sokolovskyi@lpnu.ua

DOI 10.29038/2524-2679-2021-01-283-299

\section{ПИТАННЯ НАЦІОНАЛЬНИХ МЕНШИН У РОЗВИТКУ ТРАНСКОРДОННОЇ СПІВПРАЦІ КАРПАТСЬКОГО СВРОРЕГІОНУ}

У статті досліджено роль національних меншин у розвитку транскордонної співпраці в Карпатському єврорегіоні. Єврорегіон «Карпати» $\epsilon$ одним із найбільших на теренах Східної та Центрально-Східної Свропи, до якого входять такі держави, як Украйна, Польща, Словаччина, Угорщина та Румунія. Стратегія ефрективного розвитку єврорегіону дає чудові можливості для розширеного політичного діалогу, а також поглибленої економічної, культурної та міжетнічної співпраці. Чимало

(C) Соколовський O., 2021 